\title{
Note: Aphis vitalbae Ferrari, 1872 (Hemiptera: Aphididae): new finding on ornamental Clematis spp. in Poland
}

\author{
Roman Hałaj • Barbara Osiadacz
}

Received: 19 March 2014 / Accepted: 29 May 2014 /Published online: 9 June 2014

(C) The Author(s) 2014. This article is published with open access at Springerlink.com

\begin{abstract}
Aphis vitalbae Ferrari is reported from Poland for the first time on ornamental clematis (Clematis spp.). The distribution of this aphid in Europe and its possible expansion route are presented with a key to identifying the aphids infesting Clematis plants in Europe.
\end{abstract}

Keywords Climatic changes - Invasiveness forecast . Local populations $\cdot$ Potential pest $\cdot$ Species acclimatization $\cdot$ Zoogeography

The species of Clematis are infested by 27 aphid species (Blackman \& Eastop 2014), of which nine belong to the genus Aphis. Three of those species (A. fabae Scopoli, 1763; A. gossypii Glover, 1877; and A. nerii Boyer de Fonscolombe, 1841) are polyphagous and infest various plants of different genera and families, while the remaining six (A. brachysiphon Narzikulov, 1964; A. clematidis Koch, 1854; A. clematicola Pashtshenko, 1994; A. clematiphaga Pashtshenko, 1994; A. longituba Hille Ris Lambers, 1966; A. vitalbae Ferrari, 1872) are narrow oligophagous, solely infesting the species of Clematis (Holman 2009). Most reports of

\section{R. Hałaj}

The Upper Silesian Nature Society,

PL 40-543 Katowice, Poland

B. Osiadacz $(\bowtie)$

Department of Entomology and Environmental Protection,

Poznań University of Life Sciences,

PL 60-594 Poznań, Poland

e-mail: osiadacz@up.poznan.pl these species concern the central and eastern Palearctic (Hille Ris Lambers 1966; Kumar \& Burkhardt 1970; Narzikulov \& Daniyarova 1990; Pashchenko 1997). So far three species of Aphis have been found to infest clematis plants in Europe (Holman 2009), and only two have been reported from Poland (Osiadacz \& Hałaj 2010). Besides polyphagous A. fabae, the oligophagous A. clematidis has been found in some regions of Poland (Osiadacz \& Hałaj 2009). The material gathered from Clematis x vitalba $\mathrm{L}$. in Upper Silesia included A. vitalbae [apterae and alate viviparae, Zabrze city, 14.07.2012, leg. M. Kręciała, Ruda Śląska city, 10.09.2012, leg. R. Hałaj; apterae males and oviparae, Zabrze city, 7.10.2013, leg. M. Kręciała, Bytom city, 02.11.2013, leg. B. Osiadacz; the evidence has been deposited in the collection of Department of Entomology and Environmental Protection, Poznań University of Life Sciences]. The addition of $A$. vitalbae comes to 758 the Poland fauna of Aphidomorpha (Osiadacz \& Hałaj 2012). A. vitalbae can be discriminated from A. clematidis on the basis of shorter hairs on appendages and lack of powdery wax (see key). Its 2-yearlong occurrence and the overcoming of the reproduction barrier (the occurrence of sexuales generation see Fig. 1) indicates it has become naturalized in Poland. The species show the ability to build up large local populations in the country they enter [the mean number of aphid individuals on one over-20-year-old plant about $3 \mathrm{~m}$ high: 2,200 individuals - Zabrze, 16.07.13; 1,900 individuals - Ruda Ślaska, 17.07.13; 2,000 individuals - Bytom, 18.07.13]. This may lead to an invasive outbreak in the future. 


\section{Key to aphids on Clematis spp. in Europe}

1. Siphunculi with a distinct subapical zone of polygonal reticulation .................................................................2

-. Siphunculi without subapical polygonal reticulation

2. Siphunculi 2.3-3.2 times longer than cauda. Longest hairs on antennal segment III maximum $0.4 \times$ basal diameter of this segment. Living apterae whitish green with dark apices to antennal segments, legs and cauda Macrosiphum (Macrosiphum) atragenae Holman, 1980

-. Siphunculi 1.7-2.2 times longer than cauda. Longest hairs on antennal segment III 0.7-1.0 $\times$ basal diameter of this segment. Living apterae usually green, sometimes yellowish or pink with femora and siphunculi pale or only slightly darker towards apices Macrosiphum (M.) euphorbiae (Thomas, 1878) 3. Spiculose head. Antennal tubercles well-developed, steep-sided or apically convergent. Abdominal tergites 1 and 7 without marginal tubercles

-. Non spiculose head. Antennal tubercles undeveloped or weakly developed. Abdominal tergites 1 and 7 with marginal tubercles

4. Siphunculi with contrastingly black distal sections ......................................... (Myzus (Mys) varians Davidson, 1912

-. Siphunculi pale, or dusky only at apices .....

.5

5. Siphunculi clavate. Antennal segment III without secondary rhinaria. Living apterae not shiny (matte), variable from whitish or pale yellowish green to mid-green, rose-pink or red, rather uniformly colored Myzus (Nectarosiphon) persicae (Sulzer, 1776)

-. Siphunculi tapering. Antennal segment III usually with 1-2 small secondary rhinaria near base. Living apterae are shiny pale whitish or yellowish green with darker green, orange or rust-colored spots at bases of siphunculi, to dull green or greenish brown ...................................................... Aulacorthum (Aulacorthum) solani (Kaltenbach, 1843) 6. Cauda black like siphunculi. Living apterae dull black, sometimes with white wax markings Aphis (Aphis) fabae Scopoli, 1763

-. Cauda pale or dusky. Living apterae not dull black

7. Apical segment of rostrum 0.75-1.0 times longer than second segment of hind tarsus. Living apterae with white wax powder, dorsum dark olive green with a blackish spinal stripe, marbled. Body length 1.7$2.3 \mathrm{~mm}$. Aphis (A.) clematidis Koch, 1854

-.Apical segment of rostrum 1.1-1.7 times longer than second segment of hind tarsus. Living apterae without wax, dorsum color varying from very dark green to pale green or yellowish in summer, often with a darker green stain sometimes resembling the letter " $\mathrm{H}$ ". Body length $1.2-1.9 \mathrm{~mm}$ Aphis (A.) vitalbae Ferrari, 1872

A. vitalbae is known from southern Europe (Nieto Nafría 2013). Its occurrence in France (Leclant 1978), Greece (Remaudière 1982), Italy (Barbagallo \& Patti 1993; Barbagallo \& Stroyan 1982) and Spain (Nieto Nafría et al. 2006) suggests that it is probably a Mediterranean element. An analysis of other records (Holman 1991; Holman \& Pintera 1981; Taschev 1964) indicates its expansion to the north. Via Bulgaria (Taschev 1964), Romania (Holman \& Pintera 1981) and the Czech Republic (Holman 1991), the species crossed the mountain barrier of the Carpathians and the Sudetes (Fig. 2), probably passing through the Moravian Gate. The region is a natural hollow area between the Western Carpathians and Eastern Sudetes and constitutes one of the main routes both for plants and animals (Osiadacz and Wojciechowski 2008; Šmarda 1956; Sternberg 1998). The phenomena of range expansion are quite frequently noted both among indigenous European aphid species (e.g. Vučetić et al. 2014) and the alien ones (e.g. Barjadze \& Ben-Dov 2011; Barjadze et al. 2011b; Hałaj et al. 2011). The reason for this can be the introduction through plant trade, now intensified and sometimes uncontrolled in terms of pest control (Hałaj et al. 2011). Additionally, the changing climatic conditions can have had some impact (Hałaj \& Osiadacz 2014; Osiadacz \& Hałaj 2014). Aphid infestation can cause damage and deformation of plant organs. Aphids are also among important vectors of contagious diseases (Harris \& Maramorosch 1977). These two aspects together result in the fact that aphids can cause significant 


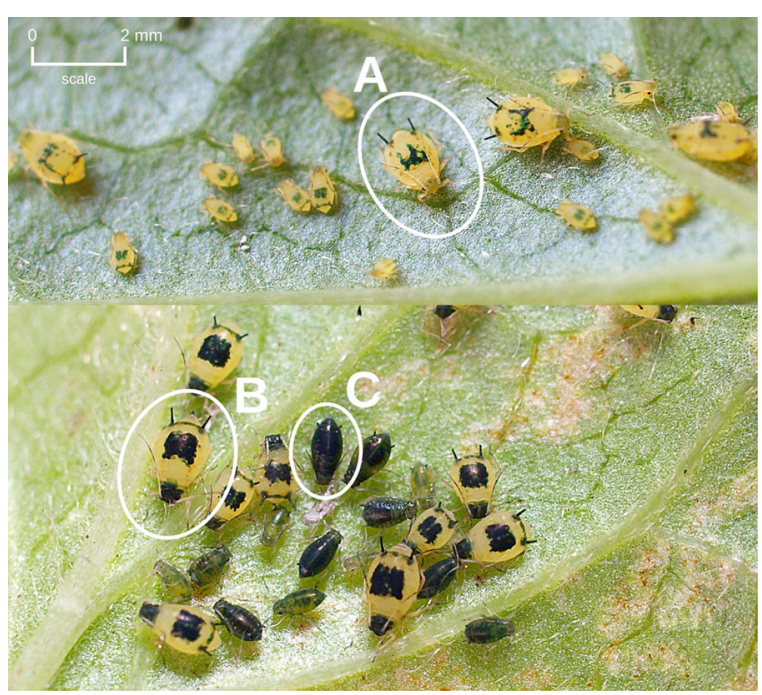

Fig. 1 Morphs of Aphis vitalbae: A - viviparous female (14 July 2013); B - oviparous female (6 October 2013), C - male (6 October 2013) [photo by M. Kręciała]

damage to crops or lower plants' commercial value (e.g. Barjadze et al. 2011a; Hałaj \& Osiadacz 2013); hence every new pest should be reported and monitored. A. vitalbae was observed to cause premature drying of leaf ends and the deformation of young shoots if it infested the bottom part of clematis leaves in large colonies (30-50 individuals). This significantly lowers the esthetic value of these decorative plants. On the other hand, the appearance of this aphid on young plants leads to plant withering, which can certainly result in tangible losses to the growers.

Open Access This article is distributed under the terms of the Creative Commons Attribution License which permits any use, distribution, and reproduction in any medium, provided the original author(s) and the source are credited.

\section{References}

Barbagallo, S., \& Patti, I. (1993). Note faunistiche sugli Afidi (Homoptera, Aphidoidea) della Puglia (Italia sud-orientale). Bollettino di Zoologia Agraria e di Bachicoltura (Ser. II), 25, 213-243.

Barbagallo, S., \& Stroyan, H. L. G. (1982). Osservazioni biologiche, ecologiche e tassinomiche sull'afidofauna della Sicilia. Frustula Entomologica (N.S.), 3, 1-182.

Barjadze, S., \& Ben-Dov, Y. (2011). The grapevine aphid Aphis illinoisensis: an invasive pest in Israel. Phytoparasitica, 39, 55-57.

Barjadze, S., Karaca, İ., Yaşar, B., \& Gratiashvili, N. (2011a). Note on Wahlgreniella nervata (Gillette, 1908) (Hemiptera: Aphididae): a new pest of Damask rose in Turkey. Phytoparasitica, 39, 239-241.

Barjadze, S., Karaca, İ., Yaşar, B., \& Japoshvili, G. (2011b). The yellow rose aphid, Rhodobium porosum (Sanderson, 1900) (Hemiptera: Aphididae): a new pest of Damask rose in Turkey. Phytoparasitica, 39, 59-62.

Blackman, R. L., \& Eastop, V. F. (2014). Aphids on the world's plants. An online identification and information guide. http:// www.aphidsonworldsplants.info. Accessed 17 March 2014.
Fig. 2 Distribution and probable expansion route of Aphis vitalbae range in Europe (1 - new localities of Aphis vitalbae in Poland; 2 - localities of Aphis vitalbae in Europe, 3 - compact range of Aphis vitalbae)

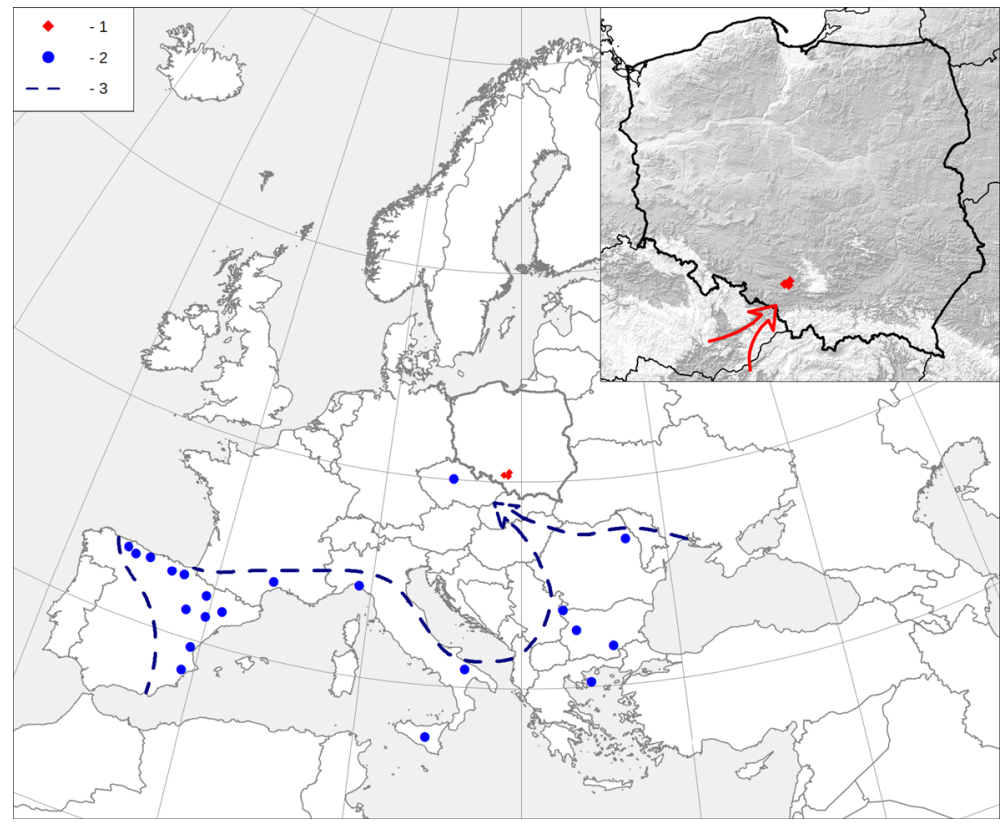


Hałaj, R., \& Osiadacz, B. (2013). European gall-forming Pemphigus (Aphidoidea: Eriosomatidae). Zoologischer Anzeiger, 252, 417-423.

Hałaj, R., \& Osiadacz, B. (2014). Ctenocallis israelica - first record in Central Europe, with a note on the genus Ctenocallis. Turkish Journal of Zoology, 38, 35-41.

Hałaj, R., Osiadacz, B., Klejdysz, T., \& Strażyński, P. (2011). Viteus vitifoliae (Fitch, 1885) a new species of aphid (Hemiptera: Aphidomorpha: Phylloxeridae) in Poland. Polish Journal of Entomology, 80, 457-464.

Harris, K. F., \& Maramorosch, K. (1977). Aphids as virus vectors. New York, NY: Academic Press.

Hille Ris Lambers, D. (1966). New and little-known aphids from Pakistan. Tijdschrift Voor Entomologie, 109, 193-220.

Holman, J. (1991). Aphids (Homoptera, Aphidoidea) and their host plants in the botanical garden of Charles University in Prague. Acta Universitatia Carolinae Biologica, 35, 19-55.

Holman, J. (2009). Host plant catalog of aphids. Palearctic Region. Dordrecht, the Netherlands: Springer.

Holman, J., \& Pintera, A. (1981). Übersicht der Blattläuse (Homoptera, Aphidoidea) der Rumänischen Sozialistischen Republik. Prague, Czechoslovakia: Academia.

Kumar, R., \& Burkhardt, C. C. (1970). A new genus, Longirostris, a new species and a new subspecies of aphids from India (Homoptera: Aphididae). Journal of the Kansas Entomological Society, 43, 458-464.

Leclant, F. (1978). Etude bioécologique des aphides de la région méditerranéenne: implications agronomiques. Thèse de Doctorat d'Etat. Montpellier: Université des Sciences et Technique du Languedoc.

Narzikulov, M. N., \& Daniyarova, M. M. (1990). Aphids of Tajikistan and neighbouring areas of Middle Asia (Homoptera, Aphidinea, Aphidinae, Aphidini). Fauna Tadzhikistan, 9(3), 1-265.

Nieto Nafría, J. M. (2013). Fauna Europaea: Aphidoidea. Fauna Europaea version 2.6.1, http://www.faunaeur.org. Accessed 1st March 2014.

Nieto Nafría, J. M., Mier Durante, M. P., García Prieto, F., \& Pérez Hidalgo, N. (2006). Hemiptera. Aphididae III. Fauna Ibérica, 19, 1-362.

Osiadacz, B., \& Hałaj, R. (2009). The aphids (Hemiptera: Sternorrhyncha: Aphidinea) of Poland: a distributional checklist. Polish Entomological Monographs, 6, 1-96.
Osiadacz, B., \& Hałaj, R. (2010). Systematic review of aphids (Hemiptera: Sternorrhyncha: Aphidomorpha) of Poland with host plant index. A monographic survey. Silesian Natural History Monographs, 1, 1-192.

Osiadacz, B., \& Hałaj, R. (2012). The update of systematic review of aphids (Hemiptera: Sternorrhyncha: Aphidomorpha) of Poland with host plant index. Wiadomości Entomologiczne, 31, 230-241.

Osiadacz, B., \& Hałaj, R. (2014). First records of gall-inducing aphid Pemphigus populi (Hemiptera: Aphidoidea, Eriosomatidae) in Poland with gall-based key to Central and North European species of the genus. Entomologica Fennica, 25, 16-26.

Osiadacz, B., \& Wojciechowski, W. (2008). Aphids (Hemiptera: Aphidinea) of the Ojców National Park. Structure and origin of fauna. Annals of the Upper Silesian Museum in Bytom. Natural History, 18, 1-172.

Pashchenko, N. F. (1997). Tli roda Aphis (Homoptera, Aphidinea, Aphididae) dal'nego vostoka Rossii. Soobshcheniye 9. [Aphids of the genus Aphis (Homoptera, Aphidinea, Aphididae) from the Russian Far East. Communication 9]. Zoologicheskiy Zhurnal, 76, 1025-1034.

Remaudière, G. (1982). Contribution à la connaissance des aphides (Homoptera, Aphidoidea) de la Grèce et description d'un Thelaxes nouveau. Annales de l'Institut Phytopathologique Benaki (N. S.), 13, 99-119.

Šmarda, J. (1956). Význam Moravské brány po migraci teplomilných rostlin z panonské oblasti do slezské nížiny. [The significance of the Moravian Gate in the thermophilous plants migration from the Pannonian region to the Silesian Lowland]. Časopis Slezského Musea A, 5, 57-69.

Sternberg, K. (1998). Die postglaziale Besiedlung Mitteleuropas durch Libellen, mit besonderer Berücksichtigung Südwestdeutschlands (Insecta, Odonata). Journal of Biogeography, 25, 319-337.

Taschev, D. G. (1964). Neubeschreibung der Art Aphis vitalbae Ferr., 1872 (Hom., Aphid.). Annuaire de l'Université de Sofia, 57, 59-68.

Vučetić, A., Jovičić, I., \& Petrović-Obradović, O. (2014). Several new and one invasive aphid species (Aphididae, Hemiptera) caught by yellow water traps in Serbia. Phytoparasitica, 42, 247-257. 